Creative Commons User License: CC BY-NC-ND

Abstracted by: EBSCOhost, Electronic Journals Service (EJS),

Google Scholar, Journal Seek, Scientific Commons,

Food and Agricultural Organization (FAO), CABI and Scopus

http://eoi.citefactor.org/10.11226/v23i4
Journal of Agricultural Extension

Vol. 24 (1) January, 2020

ISSN(e): 24086851; ISSN(Print); 1119944X

http://journal.aesonnigeria.org

http://www.ajol.info/index.php/jae

Email: editorinchief@aesonnigeria.org

\title{
Adoption of Bio-security Measures against Avian-Influenza Outbreaks among Poultry Farmers in Jigawa State, Nigeria \\ https://dx.doi.org/10.4314/jae.v24i1.9
}

\section{Oladipo, Felix Olayinka}

Departments of Agricultural Extension and Rural Development, University of Ilorin, Nigeria felixoladipo5@gmail.com, +2348032275101

\section{Bello, Oladele Gafaru}

Department of Agricultural Economics and Extension, Federal University Dutse, Nigeria bellogfaro@gmail.com, +2348039662556

\section{Daudu, Abdulrasaq Kamal}

Departments of Agricultural Extension and Rural Development, University of Ilorin, Nigeria daudu.ak@unilorin.edu.ng, +2348032853580

\section{Kayode, Ajoke Oluwatoyin}

Departments of Agricultural Extension and Rural Development, University of Ilorin, Nigeria toyinkayode2000@yahoo.com, +2348067309397

\section{Kareem, Oyedola Waheed}

Departments of Agricultural Extension and Rural Development, University of Ilorin, Nigeria abdulkareem.wahid@gmail.com, +2348032151063

\section{Olorunfemi, Oluwasogo David}

Departments of Agricultural Extension and Rural Development, University of Ilorin, Nigeria davidsoa2003@yahoo.com, +2348034571177

\section{lyilade, Abigail Oluwatunmise}

Agricultural and Rural Management Training Institute (ARMTI), Ilorin, Nigeria iyiladeabigail@gmail.com

\section{Abstract}

The study examined the adoption of selected bio-security measures against avian-influenza (HPAl-A/H5N1) outbreaks among poultry farmers in Jigawa State, Nigeria. A total of 120 respondents selected through a multistage sampling procedure was used for the study. Structured questionnaire was used to elicit information from the respondents. Data collected were subjected to percentages, mean and binary regression. The study revealed that the high level of adoption on biosecurity measures of segregation and traffic control $(\bar{x}=2.82)$, medium level of adoption for cleaning $(\bar{x}=2.440)$ and low level of adoption for disinfection of the standard bio-security components $(=1.290)$. There was a positive and significant relationship between 
Creative Commons User License: CC BY-NC-ND

Abstracted by: EBSCOhost, Electronic Journals Service (EJS), Google Scholar, Journal Seek, Scientific Commons,

Food and Agricultural Organization (FAO), CABI and Scopus
Journal of Agricultural Extension

Vol. 24 (1) January, 2020

ISSN(e): 24086851; ISSN(Print); 1119944X

http://journal.aesonnigeria.org

http://www.ajol.info/index.php/jae

Email: editorinchief@aesonnigeria.org

some socio-economic characteristics (age, average monthly income, farming experience and membership of social group) and adoption of bio-security measures of poultry farmers. Constraints to adoption of biosecurity measure poultry tension/veterinary contact, lack of buffer areas $(\bar{x}=3.21)$ around the farm site and inadequate access to fund $(\bar{x}=3.21)$. Provision of accessible and affordable credit facilities by government to poultry farmers, and extension agents should intensify more effort on continuous training and constant veterinary services for poultry farmers in the study area towards increased capability to eradicate the negative effect of this acute and highly contagious viral disease on their means of livelihood.

Keywords: Adoption of bio-security, avian-influenza, outbreak, poultry farmers.

\section{Introduction}

The Nigerian poultry industry is the most popular livestock enterprise adopted by small and medium scale farmers in both rural and urban areas of Nigeria (Afolayan Bawa, Sekoni, Abeke, and Daramola, 2014). According to Ozoedu, Eseonu, and Emanalom (2015), poultry production is the fastest means of correcting the shortage of animal protein intake, because it has the best efficiency of nutrient transformation into high quality animal protein except for the negative effects of reportable viral poultry diseases. However, promising as it seems, it has been faced or battling with a myriad of daunting challenges. Among these challenges is the Avian Influenza H5N1 popularly known as bird flu which was first reported in Kaduna in 2006. The Highly Pathogenic Avian Influenza (HPAI) is a devastating virus infection of the strain H5N1 usually associated with high mortality rates which may lead to disruptions in production and trade. The disease, being zoonotic, may be transmitted from birds to humans and is a potential source of future human influenza epidemic (Wakawa Abdu, Oladele, Sa'idu, and Owoade, 2012).

Avian influenza (AI) viruses belong to the Influenza Virus A genus of the Orthomyxovirus family and can be divided into two distinct groups on the basis of their ability to cause disease: highly pathogenic avian influenza (HPAl) and low pathogenic avian influenza (LPAl) viruses. Infection with HPAI viruses in poultry can result in $100 \%$ flock mortality while LPAI viruses cause primarily respiratory diseases. HPAI is a viral disease affecting the digestive, nervous and respiratory systems of all domestic and wild birds that is characterized by reproductive, respiratory, nervous and/or digestive signs with high morbidity and mortality with an incubation period of few hours to few days Ezeh, Ezeh and Afolayan (2017). It is highly contagious and may be fatal in humans. The disease affects all ages, but is more serious in the young humans. 
Creative Commons User License: CC BY-NC-ND

Abstracted by: EBSCOhost, Electronic Journals Service (EJS), Google Scholar, Journal Seek, Scientific Commons,

Food and Agricultural Organization (FAO), CABI and Scopus
Journal of Agricultural Extension

Vol. 24 (1) January, 2020

ISSN(e): 24086851; ISSN(Print); 1119944X

http://journal.aesonnigeria.org

http://www.ajol.info/index.php/jae

Email: editorinchief@aesonnigeria.org

As already mentioned, bird flu is very lethal, highly pathogenic and usually results in massive depopulation of poultry stocks any time there is an outbreak. The outbreaks reported in 2006 and 2007, firstly in Northwest (Jigawa State) and subsequently in other parts of the country, took a massive toll in its wake. Ezeh et al., (2017) estimated that over 480,000 birds were lost in four states of Kano, Kaduna, Katsina and Jigawa following the outbreak. As the poultry industry was recuperating from this onslaught after its containment in 2008, fresh outbreaks were reported in August/September, 2015. This implies that the diseases is taken a recurrent pattern and therefore pandemic is eminent. The outbreak of Avian Influenza in Nigeria has led to job losses, health problems, reduction in expected income of poultry farmers and a decrease in the demand for poultry products

Bio-security and early detection measures to reduce the risk of HPAI H5N1 introduction into poultry holdings are laid down as the best, cheap, easy and sustainable measure against infectious poultry diseases (Mulatti et al., 2016). According to Conan, Goutard, Sorn, and Vong, (2012), the HPAI spreads primarily through human activities and is susceptible to bio-security measures (BSM) along the production and marketing chain. It is this that makes bio-security an important tool for the control and eradication of H5N1 HPAI.

Bio-security involves a set of management practices which helps to reduce the potential for the introduction and spread of disease causing organism onto and between sites (FAO, 2012). Bio-security consists of two major elements which are; bio-containment (prevention of spread of the virus from one infected premise to another) and bio-exclusion (measures to exclude infectious agents from uninfected sites). According to Rimi, Sultana, Muhsina, Uddin, Haider, Nahar, Zeidner, SturmRamirez, and Luby (2017), bio-security has three major components which are cleaning, disinfection and segregation and traffic control. A good bio-security programme will not only offer protection against the devastating diseases such as Avian influenza (HPAl) and severe Newcastle disease, but by minimizing the level of all disease causing organisms in the pen or poultry site (FAO, 2012).

Given that the 2006/2007 outbreaks of bird flu took everybody off guard, being the first time, why are we having resurgent outbreaks in recent months? Are Nigerian poultry farmers aware and knowledgeable of bio-security measures (BSMs) that must be put in place to keep the disease in check? These questions coupled with the apparent dearth of information on bio-security adoption have made this study imperative.

\section{Objectives of the Study}

The broad objective of this study was to assess the adoption of bio-security measures against Avian Influenza (HPAI H5NI) epidemics among poultry farmers in Jigawa State, Nigeria. The specific objectives of the study were to;

i. examine the level of adoption of bio-security by the farmers; 
Creative Commons User License: CC BY-NC-ND

Abstracted by: EBSCOhost, Electronic Journals Service (EJS), Google Scholar, Journal Seek, Scientific Commons,

Food and Agricultural Organization (FAO), CABI and Scopus
Journal of Agricultural Extension

Vol. 24 (1) January, 2020

ISSN(e): 24086851; ISSN(Print); 1119944X

http://journal.aesonnigeria.org

http://www.ajol.info/index.php/jae

Email: editorinchief@aesonnigeria.org

ii. examine the poultry farmers' source(s) of information on bio-security against Avian Influenza virus; and

iii. identify the constraints of the farmers against adoption of these biosecurity standard practices.

\section{Hypothesis:}

$\mathbf{H}_{\mathbf{0 1}}$ : There is no significant relationship between some selected characteristics (age, farming experience, average monthly income and membership of association) and the adoption of standard bio-security measures

\section{Methodology}

The study was conducted in Jigawa State, Nigeria. The population for the study was all the poultry farmers in the state. It is situated in the north-western part of the country between latitudes $11.00^{\circ} \mathrm{N}$ to $13.00^{\circ} \mathrm{N}$ and longitudes $8.00^{\circ} \mathrm{E}$ to $10.15^{\circ} \mathrm{E}$. The state has twenty seven (27) local government_(National Population Commission, NPC, 2006). It shares boundaries with three (3) states and Niger Republic. The mean temperature ranges from $35^{\circ} \mathrm{C}$ in October to about $50^{\circ} \mathrm{C}$ in May, while mean annual rainfall varies from $700 \mathrm{~mm}$ to over $1000 \mathrm{~mm}$ and can last up to 200days in some lowland parts of the state. The months of November to March are particularly cold due to dry harmattan wind. Jigawa state is predominantly an agrarian state with over $80 \%$ of the population involved in Agriculture. The major livestock kept in the state includes, small ruminants (sheep and goat), poultry, and cattle.

- Zone 1; with headquarters in Brinin kudu comprises of Dutse, Kiyawa, Jahun, Buji, Brinikudu, Gwaram, and Miga;

- Zone 2; with headquarters in Gumel comprises of Gumel, Maigatari, Ringim, Taura, Gagarawa;

- Zone 3; with headquarters in Hadejia comprises of Briniuwa, Kirikasamma, Kafin-Hause, Auyo, Guri, Malamadori, Kaugama, Hadejia; and

- Zone 4; with headquarter in Kazaure comprises of Kazaure, Yankwashi, Gwiwa, Roni, Suletankarkar, Babura, Garki.

A multi-stage (three stage) sampling procedure was employed in the study. The first stage was a random selection of two local governments from each Agricultural development Programme (ADP) zones of the state. The second stage was a random selection of five (5) communities from each of the selected local governments. The selected local governments were; Dutse and Brinin-kudu for Zone 1, Gumel and Maigatari for Zone 2, Hadejia and Kafin-Hausa for Zone 3 and Kazaure and Babura for Zone 4 respectively. The third stage was a random selection of three poultry farmers from each of the communities from the list of poultry farmers (registered poultry farmers under the Poultry Association of Nigeria-PAN) in each community obtained from JARDA to give a sample size of 120 respondents for the study. The 
Creative Commons User License: CC BY-NC-ND

Abstracted by: EBSCOhost, Electronic Journals Service (EJS),

Google Scholar, Journal Seek, Scientific Commons,

Food and Agricultural Organization (FAO), CABI and Scopus
Journal of Agricultural Extension

Vol. 24 (1) January, 2020

ISSN(e): 24086851; ISSN(Print); 1119944X

http://journal.aesonnigeria.org

http://www.ajol.info/index.php/jae

Email: editorinchief@aesonnigeria.org

data were collected with the aid of structured questionnaire and interview schedule facilitated by trained enumerators from the state Ministry of Agriculture (JARDA). The statistical analysis employed was descriptive statistics (percentages, mean, frequency counts, standard deviation). The hypothesis was tested using regression analysis.

\section{Measurement of variables}

The adoption of bio-security best practices by the poultry farmers in the study area was analyzed on a three point Likert-type scale of low adoption (LA) $=1$, medium adoption $(\mathrm{MA})=2$ and high adoption $(\mathrm{HA})=3$ respectively. The mean (mean $\bar{x})$ adoption was obtained as $1+2+3 / 3=2.00$ for the measurement of the practices in question. With an interval of 0.5 , it implies a low adoption level limit is $2-0.5=$ below 1.5 , medium adoption is 2.0 while high level limit is $2.0+0.5=2.5$ above as the case may be.

\section{Results and Discussion}

\section{Adoption of Poultry Bio-security measures}

The result of the level of adoption of bio-security practices among the poultry farmers is presented in Table 1 . The standard bio-security practices according to FAO (2012); was used and it was classified into three main components; cleaning, disinfection and segregation/traffic control components respectively. These components were further divided into sub-components and the emerging questions were asked from the respondents, coded and recorded as indicated in Table 2. In cleaning component it shows that the most adopted bio-security practices were complete/constant farm cleaning ( $\bar{x}=2.29)$, good waste disposal system and dead carcasses $(\bar{x}=2.16)$ and vehicle entry cleaning/protocol $(\bar{x}=2.11)$ among others. This implies that the respondents showed a medium level of adoption to cleaning components of the standard bio-security practices with a mean of 2.44 . In the disinfection component, the respondents mostly adopted keeping farm records of mortality/medication/vaccination $(\bar{x}=1.44)$, foot bath disinfection solution daily changing $(\bar{x}=1.37)$ and farm's specific cloth and foot wears for employees and visitors ( $\bar{x}=1.31)$ among others. This implies that respondents again only adopted disinfection component of bio-security at a low level $(\bar{x}=1.29)$ in the study area. This is in consonance with the finding of Udofia and Edet (2016) that the level of adoption of beekeeping practices in Ikot Udo Abia Community in Akwa Ibom State, Nigeria is very low because the respondents lacked compliance to some standard practices in beekeeping activities. In the segregation/traffic control component, the respondents mostly adopted employee restrictions from visiting other farms ( $\bar{x}=2.98)$, poultry houses very close to the road for ease of transportation $(\bar{x}=2.93)$ and avoidance of wild birds into poultry houses $(\bar{x}=2.90)$ among others. This further posited that this 
Creative Commons User License: CC BY-NC-ND

Abstracted by: EBSCOhost, Electronic Journals Service (EJS),

Google Scholar, Journal Seek, Scientific Commons,

Food and Agricultural Organization (FAO), CABI and Scopus

http://eoi.citefactor.org/10.11226/v23i4
Journal of Agricultural Extension

Vol. 24 (1) January, 2020

ISSN(e): 24086851; ISSN(Print); 1119944X

http://journal.aesonnigeria.org

http://www.ajol.info/index.php/jae

Email: editorinchief@aesonnigeria.org

component of bio-security showed high level of adoption ( $\bar{x}=2.82)$ among the respondents in the study area.

\section{Table 1: Adopted bio-security practices}

\begin{tabular}{|c|c|c|}
\hline Bio-security practices & $\operatorname{Mean}(\bar{x})$ & Rank \\
\hline $\begin{array}{l}\text { Hand washing with soap before and after handling birds, } \\
\text { eggs and feed etc. }\end{array}$ & 2.01 & $4^{\text {th }}$ \\
\hline Hand washing after sneezing & 2.01 & $4^{\text {th }}$ \\
\hline Hand washing after toileting & 1.98 & $7^{\text {th }}$ \\
\hline Good waste disposal system and dead carcasses & 2.16 & $2^{\text {nd }}$ \\
\hline Complete/constant farm cleaning & 2.29 & $1^{\text {st }}$ \\
\hline Visitors' entry cleaning/protocol & 2.05 & $6^{\text {th }}$ \\
\hline vehicles entry cleaning/protocol & 2.11 & $3^{\text {rd }}$ \\
\hline \multicolumn{3}{|l|}{ Disinfection components } \\
\hline $\begin{array}{l}\text { Disinfect cars, bikes, trucks, visitors and other before } \\
\text { entering the farm }\end{array}$ & 1.01 & $6^{\text {th }}$ \\
\hline Foot baths disinfectants solution changed daily & 1.37 & $2^{\text {nd }}$ \\
\hline Outside equipment bought into the farm disinfected & 1.29 & $4^{\text {th }}$ \\
\hline keep farm records of mortality/medication/vaccination etc & 1.44 & $1^{\text {st }}$ \\
\hline $\begin{array}{l}\text { Farm's specific cloth and foot wears for employees and } \\
\text { visitors }\end{array}$ & 1.31 & $3^{\text {rd }}$ \\
\hline $\begin{array}{l}\text { Constant/periodic disinfection of equipment, poultry } \\
\text { houses and clothes. } \\
\text { Segregating/traffic control }\end{array}$ & 1.29 & $4^{\text {th }}$ \\
\hline All-in-all-out system of management & 2.88 & $4^{\text {th }}$ \\
\hline $\begin{array}{l}\text { Avoidance of wild bird into poultry houses that are vectors } \\
\text { for Al }\end{array}$ & 2.90 & $3^{\text {rd }}$ \\
\hline $\begin{array}{l}\text { Other farm animals like cattle, goats etc raised on poultry } \\
\text { farm }\end{array}$ & 2.68 & $5^{\text {th }}$ \\
\hline Birds of two different age groups in the same building & 2.54 & $6^{\text {th }}$ \\
\hline $\begin{array}{l}\text { Employee restrictions from visiting other farms and vice } \\
\text { versa }\end{array}$ & 2.98 & $1^{\text {st }}$ \\
\hline $\begin{array}{l}\text { Poultry houses very close to the roads (less than } 500 \mathrm{~m} \text { ) } \\
\text { for mobility }\end{array}$ & 2.93 & $2^{\text {nd }}$ \\
\hline
\end{tabular}

\section{Source: Field Survey, 2018.}

The outcome of the categorization of the level of adoption is shown in Table 2. The cleaning component of the bio-security practices showed a medium level of adoption of the bio-security measures $(\bar{x}=2.44)$, the disinfection component showed a low level of adoption ( $\bar{x}=1.29)$ while the segregation and traffic control component of the 
Creative Commons User License: CC BY-NC-ND

Abstracted by: EBSCOhost, Electronic Journals Service (EJS), Google Scholar, Journal Seek, Scientific Commons,

Food and Agricultural Organization (FAO), CABI and Scopus
Journal of Agricultural Extension

Vol. 24 (1) January, 2020

ISSN(e): 24086851; ISSN(Print); 1119944X

http://journal.aesonnigeria.org

http://www.ajol.info/index.php/jae

Email: editorinchief@aesonnigeria.org

bio-security practices showed a high level of adoption ( $\bar{x}=2.82)$ of bio-security practices among the poultry farmers in the study area. This is also in agreement with the awareness and adoption level of quail farmers in quail production in Kwara State, Nigeria (Oladipo et.al, 2014). This is also in consonance with the submission of Ezeh et. al., (2017) that the awareness and adoption of bio-security measures among farmers in Kaduna State, Nigeria.

\section{Sources of Biosecurity Information Utilized by Poultry Farmers}

Table 2 reveals that co-farmers $(\bar{x}=3.711)$, radio $(\bar{x}=3.523)$ and marketers $(\bar{x}=3.523)$ of poultry products were the prominent utilized information sources among the poultry farmers. This is in conformity with the assertion of United Nations Educational, Scientific and Cultural Organization (2014) that youth and rural communities make use of Radio as their means of information mostly. Also, Unity for Youth (2016) asserted that most of the youth in agricultural activities first got their awareness of agricultural practices through their family/friends/neighbors in the communities where they live. This is in line with finding Tenzin et al., (2017) that the main sources of poultry farmers' information on Avian Influenza in Thimphu City Area Bhutan are friends/ neighbors, television, health officers/clinic, surveillance groups and radio.

\section{Table 2: Source(s) of information on Aaian influenza bio-security practices}

\begin{tabular}{lll}
\hline Variables & $($ Mean $\bar{x})$ & Rank \\
\hline Radio & 3.523 & $2^{\text {nd }}$ \\
Family/friends/ neighbors & 3.218 & $4^{\text {th }}$ \\
Co-farmers/farmers' group & 3.711 & $1^{\text {st }}$ \\
Extension agents/ADP & 2.310 & $5^{\text {th }}$ \\
Television & 2.119 & $6^{\text {th }}$ \\
Newspapers & 1.317 & $7^{\text {th }}$ \\
Marketers of poultry products & 3.523 & $2^{\text {nd }}$
\end{tabular}

\section{Source: Field Survey, 2018}

\section{Relationship between Selected Socio-Economic Characteristics and Adoption} of Bio-Security Measures

The results in Table 3 show that only four variables; age $\left(\bar{x}=1.371^{*}\right)$, farming experience $\left(2.127^{\star}\right)$, membership of association $\left(1.820^{*}\right)$ and average monthly income $\left(\bar{x}=1.121^{*}\right)$ where significant.. Gender was negatively significant with adoption of bio-security measures. Others show no significance to adoption of biosecurity measures against HPAI. This is in line with the submission of Ezeh et. al., (2017) on bio-security adoption of poultry farmers in Kaduna State, Nigeria. 
Creative Commons User License: CC BY-NC-ND

Abstracted by: EBSCOhost, Electronic Journals Service (EJS), Google Scholar, Journal Seek, Scientific Commons,

Food and Agricultural Organization (FAO), CABI and Scopus

http://eoi.citefactor.org/10.11226/v23i4
Journal of Agricultural Extension

Vol. 24 (1) January, 2020

ISSN(e): 24086851; ISSN(Print); 1119944X

http://journal.aesonnigeria.org

http://www.ajol.info/index.php/jae

Email: editorinchief@aesonnigeria.org

Table 3: Relationship between some selected characteristics and adoption of bio-security measures

\begin{tabular}{lll}
\hline Socioeconomic Variables & Estimate & $\begin{array}{l}\text { Std. Error } \\
\text { Estimte }\end{array}$ \\
\hline Age & $1.371^{*}$ & 1.747 \\
Sex & -1.167 & 0.640 \\
Farming Experience & $2.127^{\star}$ & 1.057 \\
Information from Extension & 1.177 & 3.129 \\
Educational Level & 2.011 & 1.044 \\
Average monthly Income & $1.121^{*}$ & 2.974 \\
Membership of Association & $1.820^{*}$ & 2.301
\end{tabular}

${ }^{*} \mathrm{P} \leq 0.05$. Source: Field survey, 2018.

\section{Constraints to Adoption of Standard Bio-Security Practices}

Table 4 shows the result of the constraints to adoption of bio-security measures among the respondents. The most severe constraints to bio-security adoption is lack of capital/ buffer areas ( $\bar{x}=3.21)$ and literacy level $(\bar{x}=2.88)$. This is in support of the finding of Anne, et.al., (2012) that, major constraints of poultry farmers to bio-security practices in developing countries are; capital to implement measures, cost of avian influenza mitigation methods, lack of education to favor understanding of the practices and others. Similarly, Ezeh et al., (2017) also found that the major constraints of poultry farmers towards avian influenza bio-security in Kaduna State Nigeria were; lack capital, lack of understanding of the bio-security procedure and cultural issues.

Table 4: Distribution of respondents by constraints to their adoption of standard bio-security practices

\begin{tabular}{lll}
\hline Variables & $($ Mean $\bar{x})$ & Rank \\
\hline Lack of buffer areas & 3.21 & $1^{\text {st }}$ \\
Lack of capital & 3.21 & $1^{\text {st }}$ \\
Illiteracy & 2.88 & $2^{\text {nd }}$ \\
High cost of bio-security measures & 2.63 & $3^{\text {th }}$ \\
Insufficient information & 2.25 & $4^{\text {th }}$ \\
Perception of the disease & 2.25 & $4^{\text {th }}$ \\
Lack of institutional support & 1.69 & $5^{\text {th }}$ \\
\hline
\end{tabular}

Source: Field Survey, 2018 
Creative Commons User License: CC BY-NC-ND

Abstracted by: EBSCOhost, Electronic Journals Service (EJS), Google Scholar, Journal Seek, Scientific Commons,

Food and Agricultural Organization (FAO), CABI and Scopus
Journal of Agricultural Extension

Vol. 24 (1) January, 2020

ISSN(e): 24086851; ISSN(Print); 1119944X

http://journal.aesonnigeria.org

http://www.ajol.info/index.php/jae

Email: editorinchief@aesonnigeria.org

\section{Conclusion and Recommendation}

The poultry farmers had medium level of adoption of cleaning component, low level of adoption of disinfection component and high level of adoption of the segregation and traffic control components to bio-security measures against HPAI virus recurrent attacks. There is need for provision of accessible and affordable credit facilities by government to poultry farmers. Extension agents should intensify more effort on continuous training and constant veterinary services for poultry farmers towards increased capability to eradicate the negative effect of this acute and highly contagious viral disease on their means of livelihood.

\section{References}

Afolayan, M., Bawa, G. S., Sekoni, A. A., Abeke, F. O., \& Daramola, S. T. (2014). Effect of inclusion level of African Locust Bean (Parkiabiglobosa) pulp in growth parameters of Egg type chicken. (0-20 weeks) Nig. J. of An. Sc., 16(1), 51-60. view at Google scholar

Anne, C, Flavie, L.G, San, S and Sirenda, V (2012). Bio-security measures for backyard poultry in developing countries: A systematic review. BMC Veterinary Research, V.8; Dec 7, 2012. Doi: 10.1186/1746-6148-8-240.

Conan, A., Goutard, F. L., Sorn, S. and Vong, S. (2012). Biosecurity measures for backyard poultry in developing countries: a systematic review. BMC Veterinary Research.

8:240. Retrieved on: 01-04-19, from; https://doi.org/10.1186/1746-6148-8240

Ezeh, C.C, O. H. Ezeh \& S. B. Afolayan, (2017). "Knowledge and attitude of poultry farmers towards bio-security against zoonotic avian influenza H5N1 in Kaduna state, Nigeria," Asian Journal of Agriculture and rural Development, Asian Economic and Social Society, vol. 7(3), pages 56-64, March.

Food and Agriculture Organization (2012). Improving biosecurity through prudent and responsible use of veterinary medicines in aquatic food production. Fisheries and Aquaculture Technical paper 547

Mulatti, P, Dorotea, T, Vieira, T.J, Bonfanti, L and Marangon, S. (2016). Effects of biosecurity measures and early detection systems, mitigation measures and surveillance strategies on the spread of HPAl and LPAI between farm. External Scientific Report. Published: 20 December, 2016. http://efsa.onlinelibrary.wiley.com

Rimi, N. A., Sultana, R., Muhsina, M., Uddin, B., Haider, N., Nahar, N., Zeidner, N., Sturm- Ramirez, K. and Luby, S. P. (2017). Biosecurity Conditions in Small Commercial Chicken Farms, Bangladesh 2011-2012. Ecohealth. 2017 Jun; 14(2): 244-258. doi: $10.1007 / \mathrm{s} 10393-017-1224-2$

Oladipo, F.O, Olorunfemi, O.D, Adefalu, L. L, Matanmi, B.M and Bello, O.G (2014). Awareness of poultry farmers on Quail production in Kwara State, Nigeria: Implication for Extension Service Delivery on Protein Nutritional Sustainability. 
Creative Commons User License: CC BY-NC-ND

Abstracted by: EBSCOhost, Electronic Journals Service (EJS), Google Scholar, Journal Seek, Scientific Commons,

Food and Agricultural Organization (FAO), CABI and Scopus

http://eoi.citefactor.org/10.11226/v23i4
Journal of Agricultural Extension

Vol. 24 (1) January, 2020

ISSN(e): 24086851; ISSN(Print); 1119944X

http://journal.aesonnigeria.org

http://www.ajol.info/index.php/jae

Email: editorinchief@aesonnigeria.org

Journal of Extension Systems, vol. 30 (2), December, 2014. www.jesonline.org/current.htm.

Ozoedu, E, Eseonu, B. O., \& Emanalom, O. O. (2015). Performance of starting broiler chicks on Sandbox (Hura crepitans). Seed meal. Nig. J. of An. Prod. 42(1), 79-84. view at Google scholar.

Tenzin, T, Chador, W and Purna, B.R (2017). Bio-security Survey in relation to the risk of HPAl outbreaks in backyard poultry holdings in Thimphu City Area, Bhuten. BMC. Vet. Res: 2017; 13.113. April 21, 2017. Doi.10.1186/s/2917.017-1033-4.

Udofia, S.I and Edet, I.B (2016). Assessment of adoption level of beekeeping practices in Ikot Udo Abia Community, Akwa Ibom State, Nigeria. Nigerian Journal of Agriculture, Food and Environment. 12(4): 98-104. December, 2016. www.njafe.org

United Nations Educational, Scientifi and Cultural Organization (The United Nations ESCO, 2014). Skills for Agriculture and Improving Rural Livelihoods' organized by UNESCO in collaboration with IFAD in Paris on 27 and 28 February 2014. http://unesdoc.unesco.org/images/0024/002457/245765e.pdf

United Nations Children's Fund (UNICEF). (2014a). Ending Child Marriage: Progress and Prospects. New York: UNICEF.

Waziri, I.M, Paul, A.A, Anthony, K.B.S and Sunday, B.O. (2013). Survey for highly pathogenic avian influenza from poultry in two northeastern states, Nigeria. Veterinary Medicine International Volume 2013. Article ID 531491, 6pages http://dx.doi.org/10:1155/2013/531491.

United Nations Children's Fund (UNICEF). (2014b). Hidden in Plain Sight: A Statistical Analysis of Violence Against Children. New York: UNICEF.

Unity for Youth (2016). Why are youth leaving farming? 2016 Youth Agribusiness, Leadership and Entrepreneurship Summit on Innovation (YALESI, 2016), held I Daker Senegal from 29 to 31 in March, 2016.www.un.org.

Wakawa, A.M., Abdu, P.A., Oladele, S.B., Sa'idu, L. and Owoade, A.A. (2012). Surveillance for avian influenza $\mathrm{H} 5$ antibodies and viruses in commercial chicken farms in Kano State, Nigeria. International Journal of Animal and Veterinary Advances, 4(5): 321325. 